\title{
Pengaruh Subtitusi Daging Ikan Madidihang Dengan Rumput Laut Kappaphycus alvarezii Terhadap Komposisi Gizi Bakso Ikan Madidihang
}

\author{
Vanessa Natali Jane Lekahena* \\ *Staf Pengajar Prodi THP FAPERTA UMMU - Ternate, e-mail: -
}

\begin{abstract}
ABSTRAK
Bakso ikan adalah makanan berbentuk bulat, terbuat dari daging ikan lumat dengan bahan tambahan lainya garam dapur, merica, tepung tapioka dan bumbubumbu. Bakso merupakan makanan yang digemari masyarakat dari semua golongan umur karena rasanya yang enak. Pembuatan bakso ikan menggunakan daging ikan madidihang adalah bentuk diversifikasi olahan ikan tersebut. Penggunaan rumput laut sebagai bahan subtitusi dalam pembuatan bakso ikan madidihang bertujuan untuk meningkatkan nilai gizi dan kualitas produk bakso ikan. Penelitian ini bertujuan untuk mengetahui pengaruh subtitusi daging ikan dengan rumput laut Kappaphycus alvarezii terhadap komposisi gizi bakso ikan madidihang dan manfaatnya untuk menghasilkan pangan berbahan dasar ikan yang berkualitas dan inovatif, sehingga mampu meningkatkan konsumsi ikan di masyarakat. Hasil penelitian subtitusi daging ikan dengan rumput laut Kappaphycus alvarezii berpengaruh sangat nyata terhadap kadar air, protein, $a b u$, lemak, karbohidrat dan serat kasar. Subtitusi daging ikan dengan rumput laut Kappaphycus alvarezii meningkatkan kadar protein, abu, karbohidrat dan serat kasar serta menurunkan kadar air dan lemak bakso ikan madidihang.
\end{abstract}

Kata Kunci: Bakso ikan, ikan madidihang, Kappaphycus alvarezii, komposisi gizi

\section{PENDAHULUAN}

Upaya mendukung gerakan makan ikan dan meningkatkan pola konsumsi ikan serta upaya pemenuhan gizi protein hewani di masyarakat, sehingga perlu adanya upaya inovatif dan kreatif dalam menghasilkan produk pangan cepat saji berbahan dasar ikan yang sehat dan bergizi. Produk hasil yang dihasilkan harus menarik, mudah diperoleh, murah dan bernilai gizi yang baik sehingga disukai oleh masyarakat.

Bakso merupakan salah satu makanan yang banyak digemari oleh semua golongan umur dalam masyarakat, karena rasanya yang enak dan cara pembuatannya yang mudah. Bakso umumnya dibuat menggunakan bahan dasar daging sapi dengan campuran bahan lainnya seperti tepung tapioka sebagai bahan pengisi, garam, gula, lada, es batu, bawang merah dan bawang putih sebagai bumbu atau bahan tambahan. Pembuatan bakso menggunakan daging ikan merupakan salah satu bentuk diversifikasi olahan ikan. Bakso ikan merupakan salah satu bentuk olahan yang menggunakan daging ikan sebagai bahan dasarnya dengan tambahan tepung tapioka dan bumbu dengan bentuk bulat halus dengan tekstur kompak, elastis dan kenyal (Adawyah, 2006).

Daging ikan yang dipilih untuk membuat bakso adalah ikan yang mempunyai daging yang berwarna putih, misalnya pada ikan tenggiri, kakap, kerapu, cunang dan lain sebagainya (Oktavianingsih, 2008). Pembuatan bakso menggunakan ikan madidihang (Thunnus albacares), merupakan salah satu alternatif pemanfaatan potensi hasil tangkapan ikan madidihang yang cukup besar di Perairan Maluku Utara. Selain itu, ikan madidihang memiliki kadar lemak rendah dan protein yang 
tinggi dengan daging putih $\pm 98 \%$ dan daging merah $\pm 2 \%$ dengan komposisi gizi sebagai berikut kadar air $70.83 \%$, protein $20.22 \%$, lemak $1.01 \%$, dan abu $0.92 \%$ sedangkan untuk komposisi SFA $22.74 \%$, MUFA $21.11 \%$ dan PUFA 55.85\% (Karunaratha dan Attygalle, 2010)

Pembuatan bakso selalu menggunakan tepung atau pati sebagai bahan pengikat. Tepung tapioka adalah salah satu bahan pengikat yang digunakan untuk meningkatkan daya ikat air, tetapi mempunyai pengaruh yang kecil terhadap emulsifikasi dalam menghasikan kualitas bakso yang baik (Soeparno, 1994). Penggunaan tepung tapioka diatas $50 \%$ dari berat daging menghasilkan bakso dengan kualitas rendah (Nurtama dan Sulistyani, 1997). Sifat fisik suatu produk pangan dapat mempengaruhi tingkat penerimaan konsumen, kualitas dan harga produk tersebut.

Penambahan tepung rumput laut dalam pembuatan bakso ikan dapat memperbaiki kualitas produk karena sifat fungsional rumput laut sebagai emulsifier (Anggadiredja et al., 1996). Selain itu, penggunaan rumput laut sebagai bahan tambahan dalam pembuatan bakso ikan dapat meningkatkan nilai gizi dan kandungan serat pada produk bakso.

Rumput laut atau algae adalah salah satu sumber daya hayati wilayah pesisir dan laut. Euchema cottonii merupakan salah satu jenis rumput laut merah (Rhodophyceae) atau dikenal sebagai Kappaphycus alvarezii karena karaginan yang dihasilkan merupakan fraksi kappa-karaginan (Samsuar, 2006). Rumput laut memiliki kandungan serat pangan (dietary fiber) sangat tinggi. Serat pangan adalah bagian dari pangan yang tidak dapat dicerna oleh enzim-enzim pencernaan (Wisnu, 2010), selain itu rumput laut juga kaya akan nutrisi esensial, seperti enzim, asam nukleat, asam amino, mikro dan makro mineral serta vitamin. Kandungan gizi rumput laut dapat meningkatkan fungsi pertahanan tubuh, memperbaiki sistem peredaran darah dan sistem pencernaan (Adhistiana et al., 2008).

Tujuan penelitian ini untuk mengetahui pengaruh subtitusi daging ikan dengan rumput laut Kappaphycus alvarezii terhadap komposisi gizi bakso ikan madidihang. Manfaat penelitian ini adalah menghasilkan produk pangan berbahan dasar ikan yang berkualitas dan inovatif, sehingga mampu meningkatkan konsumsi ikan di masyarakat.

\section{METODE PENELITIAN}

\subsection{Alat dan Bahan}

Peralatan yang digunakan untuk pembuatan bakso ikan pisau, grinder, blender, talenan, baskom plastik, panci perebusan, spatula pengaduk, saringan, kompor, timbangan, timer, dan thermometer, sedangkan peralatan untuk analisis digunakan proksimat dan serat kasar seperti dijelaskan dalam metode analisis sampel.

Bahan yang digunakan dalam pembuatan bakso yaitu daging ikan madidihang dan rumput laut Kappaphycus alvarezii serta bahan tambahan lainnya seperti bawang merah, bawang putih, merica, garam, tepung tapioka, dan air es, selain itu terdapat bahan kimia digunakan untuk analisis proksimat dan serat kasar, seperti dijelaskan pada metode analisis sampel.

\subsection{Persiapan Sampel}

Persiapan bahan baku bakso, ikan madidihang dicuci dan dibuang kepala, insang, isi perut dan kulit, selanjutnya di fillet untuk dipisahkan dari tulang. Daging ikan yang telah dipisahkan, kemudian dibersihkan dari duri dan tulang yang masih menempel, dicuci, dipotong dadu dan dihaluskan menggunakan grinder hingga menjadi daging ikan lumat. Bumbu-bumbu dan bahan tambahan lain disiapkan seperti tepung tapioka, bawang putih, bawang merah, merica dan air es.

Persiapan bahan subtitusi, rumput laut Kappaphicus alvarezii kering dicuci dan direndam menggunakan air dengan perbandingan 1: 10 selama 6-8 jam, ditiriskan, dan dipotong-potong dalam ukuran 2-3 cm, selanjutnya dihaluskan menggunakan blender dengan menambahkan air sebanyak 5 kali dari berat rumput laut hingga menjadi bubur rumput laut.

Proses pembuatan bakso ikan, daging ikan lumat yang di subtitusi dengan bubur rumput laut dicampurkan untuk pembuatan adonan bakso ikan dengan perlakuan: A0 (100\% ikan + 0\% rumput laut); A1 (95\% ikan + $5 \%$ rumput laut); A2 (90\% ikan $+10 \%$ rumput 
laut) dan A3 (85\% ikan $+15 \%$ rumput laut), kemudian ditambahkan tepung tapioka sebagai bahan pengikat sebanyak $50 \%$ dari berat adonan (campuran ikan dan rumput laut) serta bahan tambahan lainnya yaitu garam $5 \mathrm{~g}$, merica $2 \mathrm{~g}$, bawang merah $10 \mathrm{~g}$, dan bawang putih $10 \mathrm{~g}$. Adonan bakso selanjutnya dicampur merata kemudian dibentuk bulat-bulat dan direbus dalam air panas pada suhu $100 \div \mathrm{H}$ sehingga matang, di angkat, di rendam dalam air es, dan ditiriskan.

\subsection{Analisis Sampel}

\subsubsection{Kadar Air (AOAC 925.09 2005)}

Cawan aluminium dengan tutupnya dikeringkan dalam oven pada suhu 98-100 selama 15 menit dan didinginkan dalam desikator selama $\mathbf{1 0}$ menit dan ditimbang ketika mencapai suhu ruang (A). Sampel ditimbang sebanyak \pm 2 g dalam cawan (B). Cawan beserta isi dikeringkan dalam oven vakum pada suhu 98-100oC selama 6 jam, kondisi vakum pada tekanan $\leq 25 \mathrm{~mm} \mathrm{Hg}$ (3.3 kPa). Cawan dipindahkan ke dalam desikator lalu didinginkan dan ditimbang. Cawan beserta isinya dikeringkan kembali sampai diperoleh berat konstan $(C)$, dengan perhitungan:

$$
\text { Kadar Air }(\% \mathrm{bb})=\frac{\mathrm{B}-(\mathrm{C}-\mathrm{A})}{\mathrm{B}} \times 100 \%
$$

\subsubsection{Kadar Abu (AOAC 941.12 2005)}

Disiapkan cawan untuk melakukan pengabuan, kemudian dikeringkan dalam oven selama 15 menit lalu didinginkan dalam desikator dan ditimbang (A). Sampel ditimbang sebanyak \pm 3 g dalam cawan (B), kemudian dibakar dalam ruang asap sampai tidak mengeluarkan asap lagi. Selanjutnya dilakukan pengabuan di dalam tanur listrik pada suhu 400-600oC selama 4-6 jam sampai terbentuk abu berwarna putih atau memiliki berat yang tetap. Abu beserta cawan didinginkan dalam desikator kemudian ditimbang (C), dengan perhitungan:

$$
\operatorname{Kadar}(\% \mathrm{bb})=\frac{\mathrm{C}-\mathrm{A}}{\mathrm{B}} \times 100 \%
$$

\subsubsection{Protein Metode Mikro Abu Kjeldahl} (AOAC 920.87 2005)

Proses analisis protein terdiri tahapan destruksi, destilasi, dan titrasi. Pengukuran kadar protein dilakukan dengan metode kjeldahl. Sampel ditimbang sebanyak $2 \mathrm{~g}$, kemudian dimasukkan ke dalam labu kjeldahl $50 \mathrm{ml}$, lalu ditambahkan 7 g K2SO4, kjeltab $0.005 \mathrm{~g}$ jenis $\mathrm{HgO}$ dan $15 \mathrm{ml} \mathrm{H2SO} 4$ pekat dan $10 \mathrm{ml} \mathrm{H} 2 \mathrm{O} 2$ ditambahkan secara perlahan ke dalam labu dan didiamkan 10 menit di ruang asam. Contoh didestruksi pada suhu 410 oC selama kurang lebih 2 jam atau sampai cairan berwarna hijau bening. Labu kjeldahl dicuci dengan akuades 50 hingga $75 \mathrm{ml}$, kemudian air tersebut dimasukkan ke dalam alat destilasi. Hasil destilasi ditampung dalam erlenmeyer $125 \mathrm{ml}$ yang berisi $25 \mathrm{ml}$ asam borat (H3BO3) 4 $\%$ yang mengandung indikator bromcherosol green $0.1 \%$ dan methyl red $0.1 \%$ dengan perbandingan 2:1. Destilasi dilakukan dengan menambahkan $50 \mathrm{ml}$ larutan $\mathrm{NaOH}-\mathrm{Na} 2 \mathrm{~S} 2 \mathrm{O} 3$ ke dalam alat destilasi hingga tertampung 100$150 \mathrm{ml}$ destilat di dalam erlenmeyer dengan hasil destilat berwarna hijau. Lalu destilat dititrasi dengan $\mathrm{HCl} \quad 0.2 \mathrm{~N}$ sampai terjadi perubahan warna merah muda yang pertama kalinya. Volume titran dibaca dan dicatat. Larutan blanko dianalisis seperti contoh. Kadar protein dihitung dengan rumus sebagai berikut:

$$
\begin{aligned}
& \% \mathrm{~N}=\frac{(\mathrm{mL} \mathrm{HCl}-\mathrm{mL} \text { blanko }) \times \mathrm{N} \mathrm{HCl} \times 14.007 \times 100 \%}{\text { mg contoh }} \\
& \% \text { Protein }=\% \mathrm{~N} x \text { faktor konversi } * \\
& \text { *) } \mathrm{FK}=6.25
\end{aligned}
$$

\subsubsection{Kadar Lemak (AOAC 960.39 2005)}

Labu lemak disediakan sesuai dengan ukuran alat ekstraksi soxhlet yang digunakan. Labu dikeringkan dalam oven dengan suhu 105-110 oC selama 15 menit, kemudian didinginkan dalam desikator lalu ditimbang (A). Ditimbang sebanyak \pm 2 g sampel (B) dalam kertas saring, kemudian ditutup dengan kapas bebas lemak. Kertas saring beserta isinya dimasukkan ke dalam ekstraksi soxhlet dan dipasang pada alat kondensor. Pelarut heksan dituangkan ke dalam labu soxhlet secukupnya. Dilakukan refleks selama 5 jam sampai pelarut yang turun kembali menjadi bening. Pelarut yang tersisa dalam labu lemak didestilasi dan kemudian labu dipanaskan dalam oven pada suhu 105 oC. Setelah dikeringkan sampai berat tetap dan didinginkan dalam desikator kemudian labu beserta lemak ditimbang (C) dan dilakukan perhitungan kadar lemak. 
सीजि
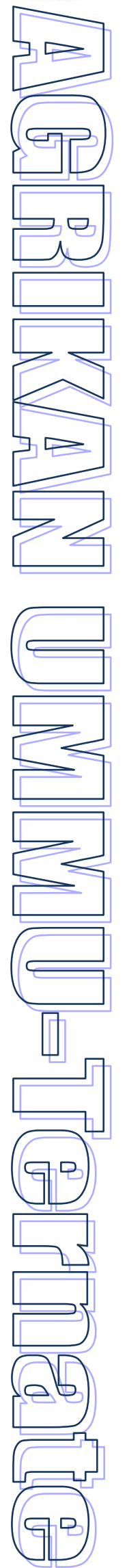

Kadar Lemak $(\%)=\frac{\mathrm{C}-\mathrm{A}}{\mathrm{B}} \times 100 \%$

2.3.5. Kadar Karbohidrat (by difference)

Kadar Karbohidrat dihitung berdasar metode by difference dengan perhitungan yaitu 100 dikurangi dengan jumlah dari kadar protein, airm abu dan lemak

\subsection{Analisis Data}

Data hasil pengujian proksimat di analisis menggunakan Rancangan Acak Lengkap (RAL) faktor tunggal (Steel dan Torrie, 1980) dan jika data hasil pengujian berpengaruh nyata, maka akan dilakukan lanjut menggunakan uji Beda Nyata Terkecil (BNT)

\section{HASIL DAN PEMBAHASAN}

Bakso ikan adalah olahan pangan berbentuk bulatan dari daging ikan bergizi tinggi dan merupakan jajanan yang telah diterima oleh masyarakat karena harganya terjangkau, memenuhi selera dan daya beli masyarakat (Agustin dan Mewengkang, 2008).
Sementara menurut SNI, (1995) bakso ikan didefenisikan sebagai bentuk olahan restrukturisasi daging yang merupakan produk pangan berbentuk bola atau lainnya, yang diperoleh dari campuran daging ikan yang di giling dan pati atau serealia dengan atau tanpa penambahan bahan-bahan kimia lain serta bahan tambahan makanan yang diijinkan.

Warna bakso yang terbuat dari daging sapi biasanya berwarna krem kecoklatan, sedangkan bakso dengan bahan baku ikan pada umumnya berwarna agak putih (Wibowo, 2004). Meskipun warna bakso bukanlah indikator utama bagi konsumen bakso untuk menerimanya. Hal ini terlihat dari hasil beberapa penelitian menunjukkan bahwa warna bakso baik dari bahan baku daging maupun ikan pada umumnya diterima (disukai).

Kandungan gizi bakso ikan madidihang disubtitusi menggunakan rumput laut Kappaphycus alvarezii seperti terlihat pada Tabel 1.

Tabel 1. Komposisi Gizi Bakso Ikan Madidihang per $100 \mathrm{~g}$ sampel (\% BB)

\begin{tabular}{lcccc}
\multicolumn{1}{c}{ Komposisi Gizi } & A1 (0\%) & A2 (5\%) & A3 (10\%) & A4 (15\%) \\
\hline \hline Kadar Air, \% & $67.92 \mathrm{~d}$ & $65.61 \mathrm{c}$ & $63.30 \mathrm{~b}$ & $61.52 \mathrm{a}$ \\
Kadar Protein, \% & $20.18 \mathrm{a}$ & $20.97 \mathrm{~b}$ & $21.58 \mathrm{c}$ & $21.85 \mathrm{c}$ \\
Kadar Abu, \% & $2.73 \mathrm{a}$ & $2.83 \mathrm{a}$ & $2.96 \mathrm{~b}$ & $3.05 \mathrm{~b}$ \\
Kadar Lemak, \% & $1.55 \mathrm{~d}$ & $1.15 \mathrm{c}$ & $0.97 \mathrm{~b}$ & $0.83 \mathrm{a}$ \\
Kadar Karbohidrat, \% *) & $7.64 \mathrm{a}$ & $9.44 \mathrm{~b}$ & $11.21 \mathrm{c}$ & $12.76 \mathrm{~d}$ \\
Serat Kasar, \% & $1.58 \mathrm{a}$ & $2.61 \mathrm{~b}$ & $3.91 \mathrm{c}$ & $5.20 \mathrm{~d}$ \\
\hline Ket. Angka yang diikuti oleh huruf yang sama pada baris yang sama tidak berbeda nyata pada $\alpha 0.05$ \\
*) Menggunakan metode by different
\end{tabular}

Subtitusi rumput laut terhadap daging ikan madidihang dalam pembuatan bakso ikan mengakibatkan meningkatkan kadar protein, abu, lemak dan serat kasar serta karbohidrat, sedangkan kadar air dan lemak mengalami penurunan. Faktor yang terutama sangat mempengaruhi kualitas bakso adalah jumlah bahan pengikat, oleh karena itu perbandingan daging ikan dan tepung tapioka yang tepat akan menghasilkan bakso dengan kualitas yang baik dari karakteristik fisik, kimia dan disukai konsumen.

\subsection{Kadar Air}

Kadar air bakso ikan madidihang adalah $61.52-67.92 \%$, dengan nilai tertinggi pada adonan dengan campuran $100 \%$ ikan dan $0 \%$ rumput laut (A1) dan terendah pada campuran $85 \%$ ikan dan $15 \%$ rumput laut (A4). Kadar air bakso ikan pada penelitian ini lebih rendah dari kadar air bakso ikan gabus dengan penambahan tepung rumput laut $5 \%$ yaitu $69.689 \%$ (Supadmi, 2011) dan bakso ikan gabus dengan penambahan konsentrasi rumput laut 0-12.5\% yaitu sebesar 66.397-75.358 (Adityia et al., 2009).

Nilai kadar air bakso ikan pada penelitian ini mengalami penurunan seiring 


\section{सी}
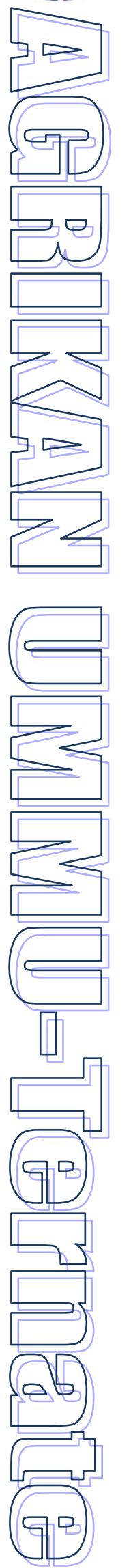

meningkatnya konsentrasi rumput laut yang digunakan untuk menggantikan daging ikan dalam pembuatan adonan bakso ikan. Hasil penelitian ini berbeda dengan pernyataan Kumolontang dan Indriaty, (2011) bahwa semakin tinggi penambahan rumput laut semakin tinggi kadar air. Analisis sidik ragam nilai kadar air menunjukkan bahwa subtitusi daging ikan dengan rumput laut berpengaruh sangat nyata terhadap kadar air bakso ikan. Hasil uji BNT menunjukkan bahwa kadar air bakso ikan madidihang pada semua perlakuan secara individu berbeda sangat nyata satu dengan lainnya.

\subsection{Kadar Protein}

Kadar protein bakso ikan madidihang berkisar antara $20.18-21.85 \%$ dengan nilai tertinggi perlakuan $85 \%$ ikan dan $15 \%$ rumput laut (A4) dan terendah pada perlakuan $100 \%$ ikan dan $0 \%$ rumput laut (A1). Subtitusi daging ikan dengan rumput laut meningkatkan kadar protein bakso ikan. Hasil ini sama dengan hasil penelitian Stefany et al, (2013) yang menyatakan bahwa kandungan protein bakso ikan yang ditambahkan rumput laut yang lebih tinggi dibandingkan dengan bakso ikan komersial. Kadar protein bakso ikan madidihang lebih tinggi dibandingkan hasil penelitian Adityia et al., (2009) yaitu 11.575$13.769 \%$.

Kadar protein bakso ikan madidihang meningkat seiring dengan meningkatnya konsentrasi rumput laut yang digunakan untuk menggantikan daging ikan dalam pembuatan bakso ikan. Analisis sidik ragam nilai kadar protein, menunjukkan subtitusi daging ikan dengan rumput laut berpengaruh sangat nyata terhadap kadar protein bakso ikan. Hasil uji BNT menunjukkan bahwa secara individu kadar protein ikan madidihang pada perlakuan A1 berbeda sangat nyata dengan perlakuan lainnya, dan perlakuan A2 berbeda sangat nyata dengan A3 dan A4, sedangkan perlakuan A3 dan A4 tidak berbeda nyata.

\subsection{Kadar Abu}

Kadar abu merupakan campuran dari komponen anorganik atau mineral yang terdapat pada suatu bahan pangan. Bahan pangan terdiri dari $96 \%$ bahan organik dan air, sedangkan sisa lainnya merupakan unsurunsur mineral (Winarno, 2008).

Kadar abu bakso ikan madidihang adalah 2.73-3.05\% dengan nilai tertinggi pada bakso ikan dengan perlakuan $85 \%$ ikan dan $15 \%$ rumput laut (A4) dan terendah pada perlakuan $100 \%$ ikan dan $0 \%$ rumput laut (A1). Kadar abu bakso ikan madidihang meningkat dengan semakin tingginya konsentrasi rumput laut yang digunakan untuk menggantikan daging ikan dalam pembuatan bakso ikan. Rumput laut Kappaphycus alvarezii memiliki kandungan mineral yang tinggi, sehingga ketika disubtitusikan untuk menggantikan daging ikan untuk pembuatan adonan bakso, menyebabkan peningkatan kadar abu bakso ikan. Kadar abu bakso ikan madidihang lebih tinggi dari kadar abu ikan gabus yang ditambahkan tepung rumput laut Eucheuma spinosum konsentrasi $5 \%$ yaitu $0.351 \%$ (Supadmi, 2011) dan hasil penelitian Adityia et al., (2009) dengan kisaran nilai antara 0.243$0.441 \%$.

Analisis sidik ragam kadar bakso ikan madidihang, menunjukkan subtitusi daging ikan dengan rumput laut berpengaruh sangat nyata terhadap kadar abu bakso ikan. Hasil uji BNT menunjukkan bahwa kadar abu pada perlakuan A1 dan A2 tidak berbeda nyata, tetapi berbeda nyata dengan $\mathrm{A} 3$ dan sangat nyata dengan $\mathrm{A} 4$, sementara perlakuan $\mathrm{A} 3$ dan A4 tidak berbeda nyata.

\subsection{Kadar Lemak}

Kadar lemak bakso ikan madidihang berkisar antara $0.83-1.55 \%$ dengan nilai tertinggi pada bakso ikan dengan perlakuan $100 \%$ ikan dan $0 \%$ rumput laut (A1) dan terendah pada perlakuan $85 \%$ ikan dan $15 \%$ rumput laut (A4). Kadar lemak bakso ikan madidihang mengalami penurunan seiring dengan meningkatnya konsentrasi rumput laut yang digunakan untuk menggantikan daging ikan dalam pembuatan bakso ikan madidihang. Rumput laut Kappaphycus alvarezii memiliki kadar lemak $\pm 0.37 \%$ dan serat kasar $\pm 0.95 \%$ sehingga ketika digunakan sebagai bahan pengganti ikan dalam pembuatan adonan bakso ikan mengakibatkan penurunan kadar lemak bakso ikan yang dihasilkan. Kadar lemak bakso ikan madidihang lebih tinggi dari 
kadar lemak bakso ikan gabus yang ditambahkan rumput laut dengan nilai berkisar antara 0.073-0.136\% (Adityia et al., 2009).

Analisis sidik ragam kadar lemak bakso ikan madidihang, menunjukkan subtitusi daging ikan dengan rumput laut berpengaruh sangat nyata terhadap kadar lemak bakso ikan. Hasil uji BNT menunjukkan bahwa kadar lemak bakso ikan pada semua perlakuan secara individu berbeda sangat nyata satu dengan lainnya.

\subsection{Kadar Karbohidrat}

Kadar karbohidrat bakso ikan madidihang berkisar antara 7.64-12.76\% dengan nilai tertinggi pada bakso ikan dengan $85 \%$ ikan dan 15\% rumput laut (A4) dan terendah pada perlakuan $100 \%$ ikan dan $0 \%$ rumput laut (A1). Makin tinggi konsentrasi rumput laut yang digunakan untuk mengganti daging ikan mengakibatkan kadar karbohidrat bakso ikan meningkat. Kadar karbohidrat pada penelitian ini lebih kecil dari hasil penelitian Adityia et al, (2009) kisaran nilai antara 10.295-21.713\%.

Kadar karbohidrat bakso ikan madidihang, mengalami peningkatan seiring meningkatnya konsentrasi rumput laut yang disubtitusikan dalam proses pembuatan bakso ikan madidihang. Selain itu, kadar karbohidrat bakso ikan juga berasal dari tepung tapioka yang digunakan sebagai bahan pengikat. Kadar karbohidrat Kappaphycus alvarezii $\pm 5.7 \%$ (Istini et al., 1986) dan glukosa yang tinggi menyebabkan kadar karbohidrat bakso ikan madidihang meningkat, sedangkan kandungan glukosa rumput laut dalam proses analisis juga terukur sebagai karbohidrat.

Analisis sidik ragam kadar karbohidrat bakso ikan madidihang, menunjukkan subtitusi daging ikan dengan rumput laut berpengaruh sangat nyata terhadap kadar karbohidrat bakso ikan. Hasil uji BNT menunjukkan bahwa kadar karbohidrat bakso ikan madidihang pada semua perlakuan secara individu berbeda sangat nyata satu dengan lainnya.

\subsection{Kadar Serat Kasar}

Kadar serat kasar bakso ikan madidihang berkisar antara $1.58-5.20 \%$ dengan nilai tertinggi pada perlakuan $85 \%$ ikan dan $15 \%$ rumput laut (A4) dan terendah pada perlakuan $100 \%$ ikan dan $0 \%$ rumput laut (A1). Kadar serat kasar bakso ikan meningkat, seiring peningkatan konsentrasi rumput laut sebagai bahan pengganti daging ikan madidihang dalam pembuatan adonan bakso. Kadar serat kasar penelitian ini lebih tinggi dibandingkan hasil penelitian Adityia et al, (2009) berkisar antara $2.703-4.499 \%$.

Analisis sidik ragam kadar serat kasar bakso ikan madidihang, menunjukkan bahwa subtitusi daging ikan dengan rumput laut berpengaruh sangat nyata. Hasil uji BNT menunjukkan bahwa kadar serat kasar bakso ikan madidihang pada semua perlakuan secara individu berbeda sangat nyata satu dengan lainnya.

Hasil penelitian Kumolontang dan Indriaty, (2011) menunjukkan bahwa penambahan rumput laut dalam pembuatan bakso ikan dapat memberikan pengaruh terhadap kadar air, kadar serat kasar dan uji organoleptik meliputi atribut citarasa, warna dan tekstur. Dikatakan pula semakin tinggi penambahan rumput laut semakin tinggi kadar air dan serat kasar sedangkan untuk uji organoleptik mengalami penurunan.

Penggunaan tepung rumput laut dalam pembuatan bakso ikan patin meningkatkan karakteristik gel bakso ikan karena komponen hidrokoloidnya hal ini ditunjukkan dengan meningkatnya kekuatan gel $(3053.36 \mathrm{~g} / \mathrm{cm})$ dan daya ikat air $(80.46 \%)$, akan tetapi dari parameter warna menghasilkan bakso yang berwarna agak gelap dengan nilai derajat putih $63.21 \%$ (Stefany et al., 2013).

\section{PENUTUP}

Hasil penelitian ini menunjukkan bahwa subtitusi daging ikan dengan rumput laut Kappaphycus alvarezii dalam pembuatan bakso berpengaruh sangat nyata terhadap kadar air (61.52-67.92\%), protein (20.18-21.85\%), abu (2.73$3.05 \%)$, lemak (0.83-1.55\%), karbohidrat (7.64$12.76 \%$ ) dan serat kasar (1.58-5.20\%). Perlakuan subtitusi daging ikan dengan rumput laut mempengaruhi komposisi gizi bakso ikan madidihang yang dihasilkan yaitu meningkatkan kadar protein, abu, lemak dan serat kasar, dan menurunkan kadar air dan lemak. 
Perlu dilakukan penelitian lanjut tentang subtitusi rumput laut terhadap daging ikan madidihang untuk menentukan mutu sensori dan umur simpan bakso ikan madidihang.

\section{DAFTAR PUSTAKA}

Adawyah R. 2006. Pengolahan dan Pengawetan Ikan.Bumi aksara. Jakarta

Adhistiana R, Rahayu MP, Ambarwati R, Herdiana E, Vivaldy. 2008. Pemanfaatan Rumput Laut Dalam Pembuatan Dodol Rumput Laut (DORULAT). Dapat diakses di. http://www.ipb.ac.id/pembuatan-rumput-laut.html. Diakses tanggal 17 Juni 2014.

Adityia, Titik S, Eddy S. 2009. Pengaruh Penambahan Tepung Rumput Laut Eucheuma spinosum Terhadap Kualitas Bakso Ikan Gabus (Ophiocephalus striatus). Dapat di akses pada: http://profeddys.blogspot.co.id/2009/06/pengaruh-rumou-tlaut-terhadap-bakso.html tanggal 25 November 2014

Agustin AT, Mewengkang HW. 2008. Keberadaan Staphylococcus sp. Pada Bakso Ikan Beku dan Suhu Ruang. Pacific Journal Maret 2008 vol. 2 (2): 91-93

Anggadiredja J, Irawati S, Kusmiyati. 1996. Seminar Nasional Industri Rumput Laut : Potensi dan Manfaat Rumput Laut Indonesia dalam Bidang Farmasi. Tim Rumput Laut BPP Teknologi. Jakarta.

AOAC [Association of Official Chemist]. 2005. Official Methods Of Analytical Of The Association Of Official Analytical Chemist. Washington, DC: AOAC.

Istini S, Zatnika A, Suhaimi, Anggadireja J. 1986. Manfaat dan Pengolahan Rumput Laut. Jurnal Penelitian BPPT. Jakarta.

Karunaratha KAAU, Attygalle MVE. 2010 Nutritional evaluation in five species of tuna Vidyodaya J. of Sci. 2010 Vo. 15 No. 1 \& 2 pp. 7-16

Kumolontang N, Indriaty F. 2011. Pengaruh Penambahan Rumput Laut Pada Pembuatan Bakso Ikan Sunglir (Elagatis bipinnulatus) Jurnal Penelitian Teknologi Industri Vol. 3 No.2 Desember 2011: 43-49 ISSN No.: 2085-580X

Nurtama B, Sulistyani Y. 1997. Buletin Teknologi dan Industri Pangan : Suplementasi Ikan Pada Makanan Ringan Produk Ekstrusi dengan Bahan Dasar Beras. Jurusan Teknologi Pangan dan Gizi Institut Pertanian Bogor. Bogor.

Oktavianingsih Y. 2008. Proses Pengolahan Bakso Ikan Lele Dumbo (Clarias gariepinus) di Desa Bandung Kecamatan Diwet Kabupaten Jombang, Jawa Timur. PKL FPIK Universitas Brawijaya. Malang.

Samsuar. 2006. Karakteristik karaginan Rumput laut Eucheuma cottonii Pada Berbagai Umur panen, Konsentrasi $\mathrm{KOH}$ dan Lama Ekstraksi. [Tesis]. Sekolah PascaSarjana Institut Pertanian Bogor. Bogor.

SNI [Standar Nasional Indonesia]. 1995. Bakso Ikan. Dewan Standarisasi Nasional. Jakarta. Soeparno. 1994. Ilmu dan Teknologi Daging. Penerbit Universitas Gajah Mada. Yogyakarta.

Steel RGD, Torrie JH. 1980. Principles and Procedures of Statistics, McGraw Hill Book Company.

Stefany, Joko Santoso Lisa A. Yakhin. 2013. Pengaruh Penambahan Tepung Rumput Laut (Eucheuma cottonii) Terhadap Karakteristik Bakso Ikan Patin. Prosiding Seminar Nasional Tahunan X Hasil Penelitian Kelautan dan Perikanan. UGM-Yogyakarta.

Supadmi. 2011. Pengaruh Penambahan Tepung Rumput Laut (Eucheuma spinosum) Terhadap Mutu Bakso Ikan Gabus (Ophiocephalus striatus). Jurnal STP Teknologi dan Penelitian Terapan. Diakses pada: http://103.7.52.118/pppm/index.php/katalog/c/75/ tanggal 25 November 2014.

Wibowo S. 2003. Pembuatan Bakso Ikan dan Daging. Penebar Swadaya. Jakarta.

Winarno FG. 2008. Kimia Pangan dan Gizi. Edisi Terbaru. Cetakan 1. M-Brio Press. Bogor.

Wisnu RA. 2010. Analisa Komposisi Nutrisi Rumput Laut (Eucheuma cottonii) dengan Proses Pengeringan Berbeda. Fakultas Teknologi Pertanian, Institut Pertanian Bogor. Bogor 